http://www.jfas.info

\title{
PHYSICOCHEMICAL CHARACTERISTICS OF MALAYSIAN HONEYS INFLUENCED BY STORAGE TIME AND TEMPERATURE
}

\author{
A. M. A. Fuad, N. Z. R. Anwar, A. J. Zakaria, N. Shahidan and Z. Zakaria
}

Faculty of Bioresources and Food Industry, Universiti Sultan Zainal Abidin, 22200 Besut, Terengganu, Malaysia

Published online: 08 August 2017

\begin{abstract}
Honey is a natural product that produced by honeybees or stingless bees. Consumers always found the best quality of honey by observing the physicochemical properties. However, storage time and temperature can affect the quality of honey. This study aimed to determine the physicochemical properties (moisture content, $\mathrm{pH}$, water activity and turbidity) of Hutan, Kelulut, Gelam, Acacia honeys stored at different temperatures $\left(-20,4\right.$ and $\left.25^{\circ} \mathrm{C}\right)$ up to 300 days and to identify the storage conditions suitable to be applied for each type of honey. The results of this study showed that the quality of Malaysian honeys were affected by the storage times and temperatures. Hutan honey was found to be very sensitive to low temperature condition. Thus, it is recommended that Hutan honey should be stored at room temperature to retain its quality.
\end{abstract}

Keywords: physicochemical characteristics; storage; Malaysian honeys.

Author Correspondence, e-mail: zaizuliana@unisza.edu.my

doi: http://dx.doi.org/10.4314/jfas.v9i2s.52

\section{INTRODUCTION}

Honey is a stable foodstuff that contains enzymes, water, carbohydrate, acids, dextrin, ash, vitamins, pollen and substance aroma [1-2]. It must be delivered to the consumers with its 
essential composition and its quality minimally altered. Nevertheless, honey undergoes natural aging once it is harvested that could reduce its quality.

Quality of honey is influenced by storage time and temperature. Honey remains in liquid form is considered having a good quality among consumers. During storage, honey tends to crystallize, but time period is different for different types of honeys. Crystallization causes several physical, chemical and biological changes in honey leading to quality degradation [3]. Prolong storage period of honey causes invert sugar to increase [4-5]. This could decline the sucrose content during the storage of honey.

Moisture content and water activity are two critical measurements for food safety and quality as both parameters can influence the shelf life of food. Moisture content can be defined as the amount of water content in food, meanwhile water activity is unbound water that can support the growth of bacteria. Honey industries are very particular in recognizing water content in honey in order to prevent spoilage of honey by fermentation [6]. However, water activity of a food system would control the microbial growth, not the water content [7]. Fermentation that caused by the growth of osmophilic yeasts such as Saccharomyces spp. would easily occur if water activity in honey is above 0.6 [8].

Previously, it was widely reported that the $\mathrm{pH}$ values for honey are in the range of $3.4-6.1$ [9]. Meanwhile, research conducted by [10] indicated that the $\mathrm{pH}$ values for Romanian honey samples were within 2.4-4.4 and within 2.8 - 4.0 for Polish samples. The variation in $\mathrm{pH}$ value is due to the enzyme reaction in honey. Enzyme functions and catalysed reactions determine honey composition, $\mathrm{pH}$ level and antibacterial properties [11].

The turbidity of honey can be a measure of the crystals formation. The liquid honey will become opaque due to the presence of glucose crystals making resulting in an increase in the absorbance value at $660 \mathrm{~nm}$ [12]. The acceptability of the consumers significantly reduced when the turbidity of honey increased as a result of crystallization process [3].

Eventhough the physicochemical properties of fresh Malaysian honeys have been reported, but limited study on the storage condition of the honeys. Thus, the purposes of this study were to determine the physicochemical of selected Malaysian honeys stored at different temperatures $\left(-20,4\right.$ and $\left.25^{\circ} \mathrm{C}\right)$ up to 300 days and to identify the storage conditions suitable 
to be applied for each type of honey in order to retain its quality for all studied parameters.

\section{RESULTS AND DISCUSSION}

\section{1. pH}

From Fig.1, it can be seen that throughout the study, Kelulut honey recorded the lowest $\mathrm{pH}$ value (2.9-3.3) when store at $25^{\circ} \mathrm{C}$ compared to other types of honeys. Lower in acidic value results in a sourness of Kelulut honey. The parameter of $\mathrm{pH}$ relates to the stability, life expectancy of honey product and fermentation process [13-14]. Hutan, Acacia and Gelam honeys also showed lower $\mathrm{pH}$ value when stored at low temperatures $\left(4\right.$ and $\left.-20^{\circ} \mathrm{C}\right)$. In this study, the temperature was found to be the factor that most significantly influenced the $\mathrm{pH}$ value $(\mathrm{P}<0.05)$. The decrease in temperature results in a drop of the reaction rate of enzyme leading to the reduction in the $\mathrm{pH}$ value. Based on these results, it is believed that low temperature could preserve the honey from being inhibited by microorganisms that require natural or basic $\mathrm{pH}$ values to grow.

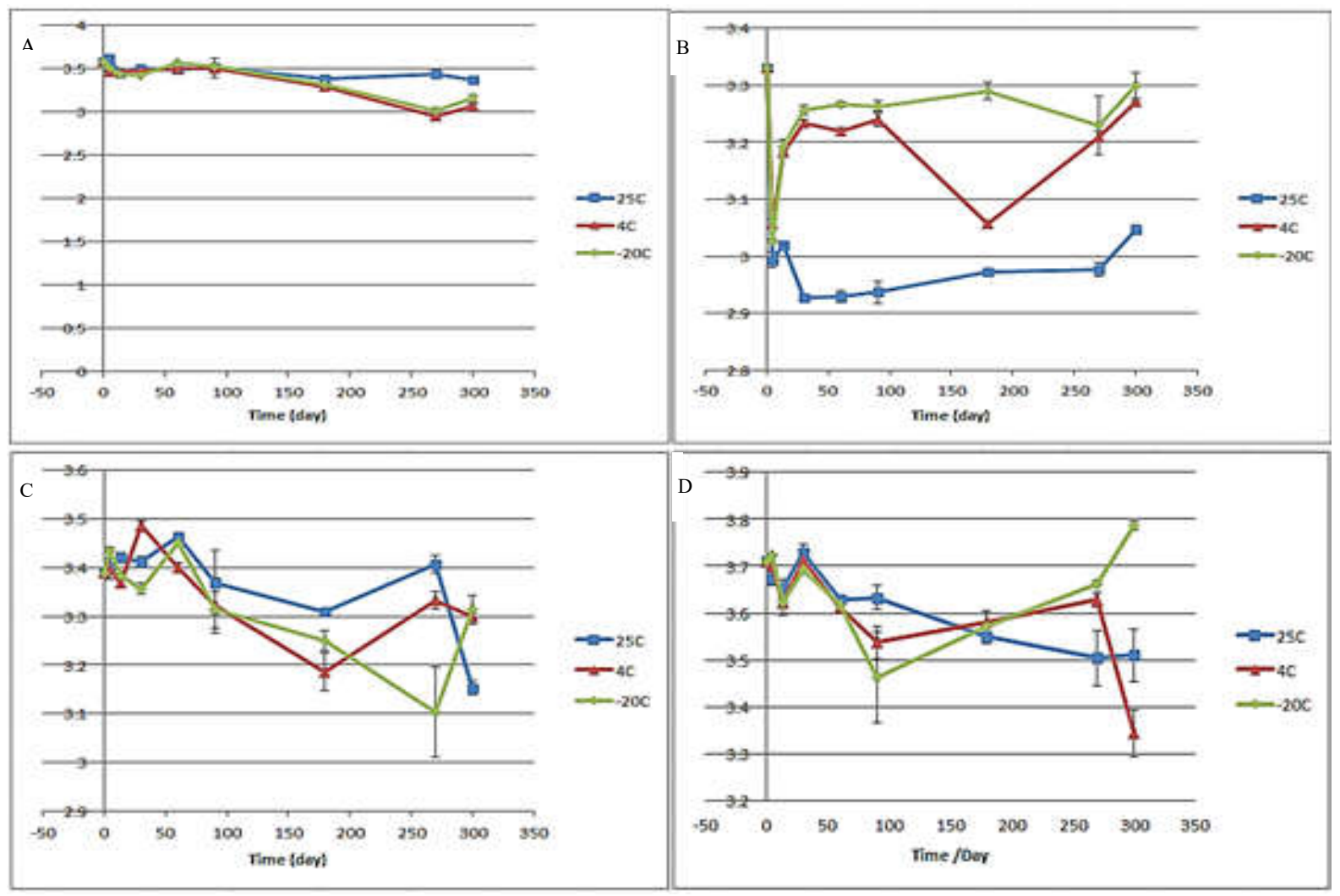

Fig.1. pH of honey ((A) Hutan; (B) Kelulut; (C) Acacia; (D)) Gelam stored at different temperatures for different storage times 


\subsection{Water Activity}

Fig.2 shows the effect of different storage temperatures and times to water activity in four types of honey. Water activity of Kelulut and Gelam honey was the highest when stored at $-20^{\circ} \mathrm{C}$, meanwhile storage temperature of $4^{\circ} \mathrm{C}$ for Hutan and Acacia honey recorded the highest water activity. In general, it can be observed that only Hutan honey have significance difference $(\mathrm{P}<0.05)$ on water activity when stored at different temperatures throughout the storage time. This showed that Hutan honey was very sensitive to the surrounding temperature as it could affect the content of water activity.

The temperature of 4 and $-20^{\circ} \mathrm{C}$ can be claimed as low temperatures which might increase the relative humidity [15]. Relative humidity is the ratio of the vapour pressure of air to its saturation vapour pressure [16]. Water activity and relative humidity are interrelated when vapour and temperature equilibrium are obtained around the sample. Honey stored at higher humidity causes the water vapour adsorption from the environment which increases the honey water activity [17]. Although the results showed that there was no significant difference $(\mathrm{P}<$ 0.05 ) on Kelulut, Acacia and Gelam honey subjected to temperatures of 4 and $-20^{\circ} \mathrm{C}$ throughout the storage time, the water activity increased when honey was exposed to lower temperature. This suggests that these three types of honey were stable when stored at 4 and $-20^{\circ} \mathrm{C}$.

Storage temperature is one of the factors that affect the crystallization in honey [18]. Honey could crystallize at 4 and $-20^{\circ} \mathrm{C}$. During crystallization, it becomes saturated and the water activity of honey will increase up to the level of the equilibrium solubility concentration [6]. Meanwhile, all water activity at $25^{\circ} \mathrm{C}$ for all types of honeys gave the lowest values throughout the storage. This confirms that less water was absorbed in honey when exposed to low humid area. Water activity of honeys may vary greatly for each type dependent on the source of honey, floral, regional and climatic conditions. 


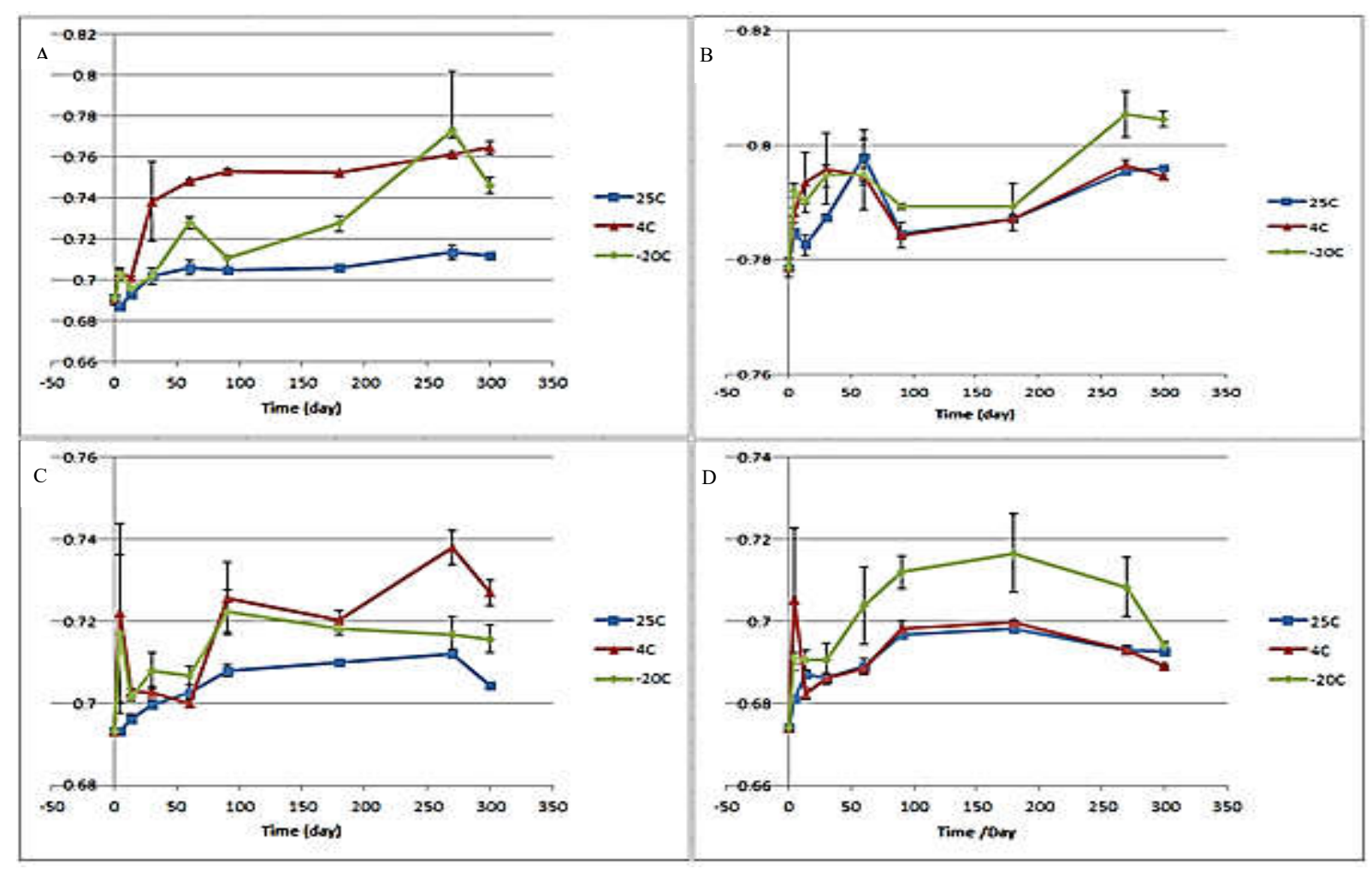

Fig.2. Water activity of honey ((A) Hutan; (B) Kelulut; (C) Acacia; (D)) Gelam stored at different temperatures for different storage times

\subsection{Moisture Content}

Honey with higher moisture content is undesirable as it could affect the honey viscosity, lead to crystallization, intrude sensory properties, solubility and preservation potential [19]. High moisture content causes honey to ferment and spoil. Thus, the shelf life of honey during storage will be affected [20]. Moisture content of different types of honey may vary as it depends on the botanical origin of the sample, the processing techniques and the storage conditions [21]. Moreover, harvesting area also influence the moisture content in honey [22].

Fig. 3 shows the effect of storage time and temperature on the moisture content of honey. The results indicate that the moisture content of Hutan, Acacia and Gelam honeys differed significantly when stored at three different storage temperatures $(\mathrm{P}<0.05)$. It can be seen that Gelam honey had the lowest moisture content in the range $15.72-22.53 \%$ for all storage times. Moisture content of Malaysian honey samples ranged between 14.46-22.32\% [23]. Thus, the value is closer to the result obtained in this study for Hutan, Gelam and Acacia honeys. Meanwhile, Kelulut honey recorded the highest moisture content value (18.59-29.61) and showed no significance difference $(\mathrm{P}=0.604)$. A similar point is made by [24] which stated 
that stingless bee honey has a different composition than Apis mellifera honey and one of the main differentials is high moisture content.

Interestingly, for all types of honeys, the moisture content was low when stored at 4 and $-20^{\circ} \mathrm{C}$. This could happen as capacity for air to hold water vapour is low when temperature decreased, thus the bond between water and air molecules has got weakened. Lower temperature has been found to have the potential to preserve the quality of honey during storage.

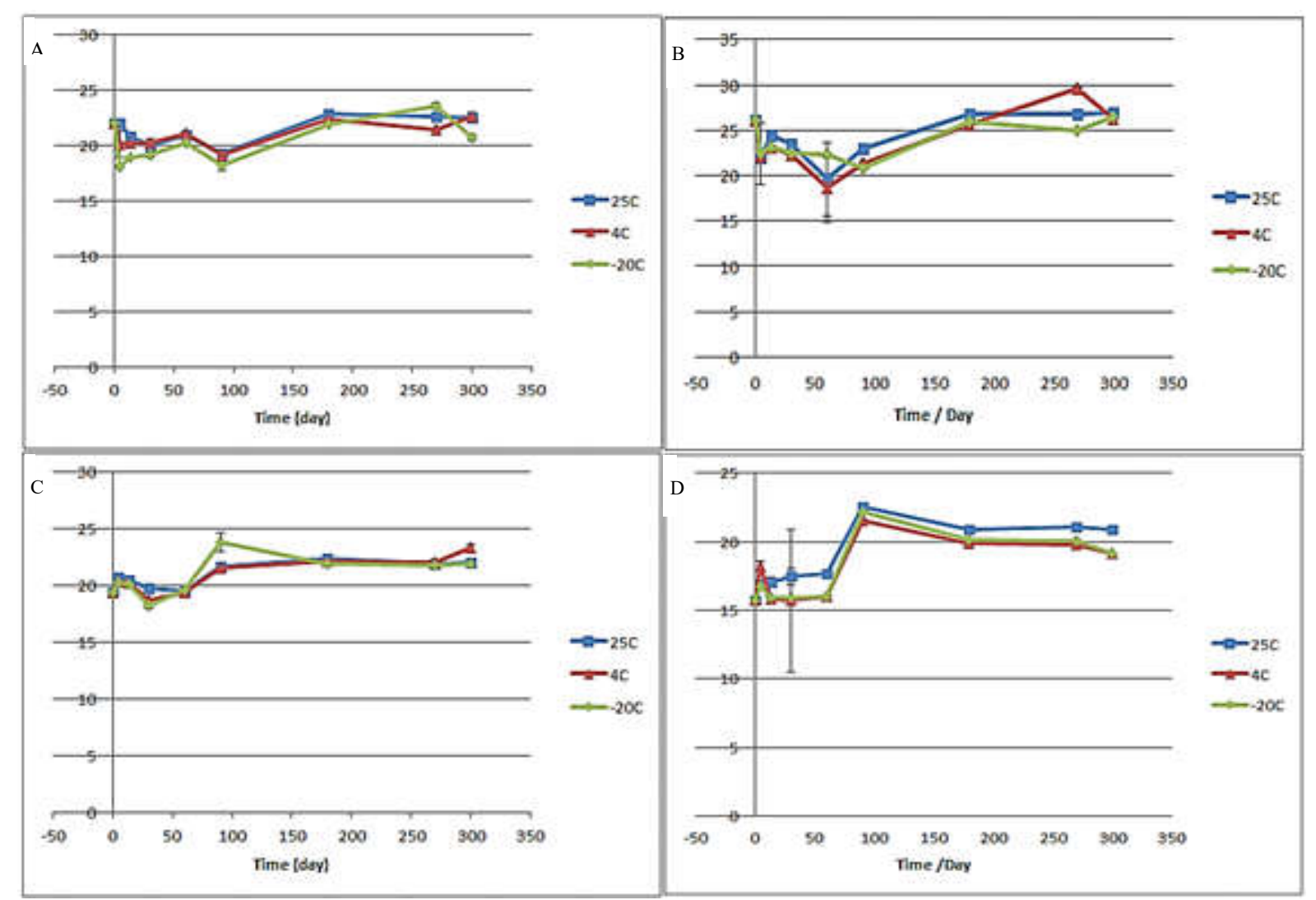

Fig.3. Moisture content of honey ((A) Hutan; (B) Kelulut; (C) Acacia; (D)) Gelam stored at different temperatures for different storage times

\subsection{Turbidity}

Fig. 4 presents the effect of storage time and temperature on honey turbidity. Turbidity of honey is contributed by the presence of crystal [25]. When crystallization occurs, the granulation might increase the absorbance value leading to the increase in the turbidity of honey as it becomes opaque [12]. Turbidity for all honey samples were significantly differences when stored at different storage temperature during storage time $(\mathrm{P}<0.05)$. From Fig. 4, turbidity for Hutan and Gelam honey stored at 4 and $-20^{\circ} \mathrm{C}$ increased drastically after 
14 days of storage. Visually, crystal formation can be seen for honey stored at $4^{\circ} \mathrm{C}$ as the formation of two layers was observed; the crystallized layer at the bottom of the jar and liquid on the top due to the gravitational force. After 90 days of storage, the turbidity of Hutan honey was found to be constant with the storage time. Meanwhile, for Kelulut and Acacia honey, the turbidity increased gradually throughout the storage time when stored at 4 and $-20^{\circ} \mathrm{C}$. At the beginning of storage time, oscillation occurred probably because of phase separation in honey due to surrounding temperature was changed.

Based on the results obtained, it indicates that Hutan and Gelam honeys are sensitive to low temperature as it can speed up the process of granulation in honey. Honeys stored at $25^{\circ} \mathrm{C}$ have lower value of absorbance in the range of 0.2-0.7 showing that honeys are suitable to be stored at room temperature as the rate of crystallization is low.

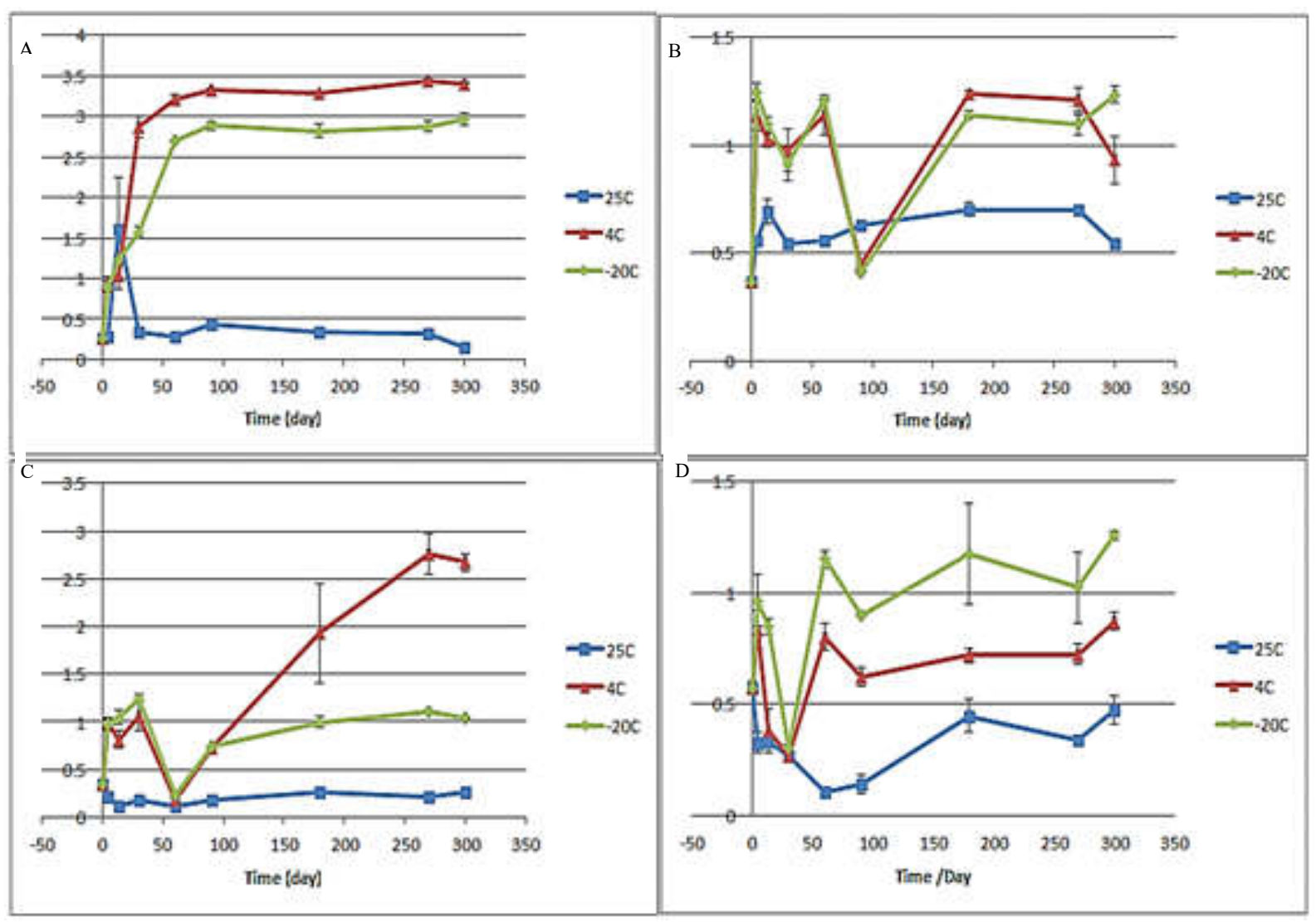

Fig.4. Turbidity of honey ((A) Hutan; (B) Kelulut; (C) Acacia; (D)) Gelam stored at different temperatures for different storage times 


\section{EXPERIMENTAL}

\subsection{Materials}

Hutan, Gelam (G, Melaleuca cajupati) and Acacia (A, Acacia mangium) were purchased from local honey manufacturer in Terengganu, while Kelulut honey was harvested from Apiari UniSZA, Tembila Campus. A volume of $40 \mathrm{ml}$ of each type of honey were kept in a clear glass container, tightly closed and stored at different temperatures $\left(-20,4,25^{\circ} \mathrm{C}\right)$ for different storage times ranging from 0 to 300 days. In all cases, the measurements were performed after gently stirring the honey in order to obtain as homogeneous as possible samples.

\subsection{Methods}

\subsubsection{Determination of $\mathbf{p H}$}

The $\mathrm{pH}$ of honey was measured using $\mathrm{pH}$ meter Basic 20. Solution of honey was prepared by dissolving $10 \mathrm{~g}$ of honey in $75 \mathrm{~mL}$ of distilled water. After the mixture was homogenized, the $\mathrm{pH}$ electrode was immersed in the solution and the $\mathrm{pH}$ value was recorded.

\subsubsection{Determination of Water activity}

Water activity $\left(a_{\mathrm{w}}\right)$ was determined by means of an Aqualab CX2 water activity meter (Decagon Devices Inc., WA, USA). The equipment was calibrated with distilled water in the $\mathrm{a}_{\mathrm{w}}$ range of 0.9 to 1.0 .

\subsubsection{Determination of Moisture Content}

The moisture content was measured by placing $3 \mathrm{~g}$ of honey sample in an oven set at $105^{\circ} \mathrm{C}$. The crucibles with cover were dried in the oven at $105^{\circ} \mathrm{C}$ and cooled in a dessicator before placing the honey samples. Crucibles were weighed soon after attaining room temperature.

\subsubsection{Determination of Turbidity}

Honey was put into a cuvette with a path-length of $1 \mathrm{~cm}$. The absorbance was measured at $660 \mathrm{~nm}$ with a spectrophotometer Beckman DU-650.

\subsubsection{Statistical Analysis}

Data were statistically analysed using the two-way analysis of variance (ANOVA), aiming at identifying differences in water activity, $\mathrm{pH}$ content, moisture content and turbidity in honey caused by the interaction of time/temperature variables. All analyses were performed using 
the SPSS 20 General Linear Model procedure (SPSS inc., USA). Significance of differences was defined at $\mathrm{P}<0.05$. All analysis was done in triplicates and average reported.

\section{CONCLUSION}

In conclusion, quality of honey would differ when stored at different storage conditions. This study found that lower temperature $\left(4\right.$ and $\left.-20^{\circ} \mathrm{C}\right)$ reduced the moisture content and $\mathrm{pH}$ of honey as these features are mostly required to retain the quality of honey. However, lower temperature had increased the turbidity of which indicates the formation of crystals increased the water activity that could lead to fermentation process. Hutan honey was very sensitive to low temperature. Thus, it is recommended to store Hutan honey at room temperature to preserve its quality.

\section{ACKNOWLEDGEMENTS}

This research was supported by the university grant (UniSZA/2015/DPU/47-R0265).

\section{REFERENCES}

[1] Silica, S. Further chemical and palynological properties of some Unifloral Turkish honey. In 1st German Bee Products and Apitherapy Congress Passau, 2002, pp. 23-27

[2] Fallico B, Zappala M, Arena E, Verzera A. Effects of conditioning on HMF content in unifloral honeys. Food Chemistry, 2004, 85(2):305-313

[3] Srinual K, Intipunya P. Effects of crystallization and processing on sensory and physicochemical qualities of Thai sunflower honey. Asian Journal of Food and Agro-Industry, 2009, 2(4):749-754

[4] White J W, Riethof M 1, Kushnir I. Composition of honey. VI. The effect of storage on carbohydrates, acidity and diastase content. Journal of Food Science, 1961, 26(1):63-71

[5] Sahinler N., Gul A. The effects of propolis production methods and honeybee genotypes on propolis yield. Pakistan Journal of Biological Sciences, 2005, 8(9):1212-1214

[6] Zamora M C, Chirife J. Determination of water activity change due to crystallization in honeys from Argentina. Food Control, 2006, 17(1):59-64 
[7] Scott W J. Water relations of Staphylococcus aureus at $30^{\circ} \mathrm{C}$. Australian Journal of Biological Sciences, 1953, 6(4):549-564

[8] Abramovič H, Jamnik M, Burkan L, Kač M. Water activity and water content in Slovenian honeys. Food Control, 2008, 19(11):1086-1090

[9] Al-Diab D, Jarkas B. Effect of storage and thermal treatment on the quality of some local brands of honey from Latakia markets. Journal of Entomology and Zoology Studies, 2015, 3(3):328-334

[10] Purcarea C, Chis A M, Dzugan M, Popovici D. Physical-chemical and biochemical characterization of selected Romanian and Polish honeydew honey. Studia Universitatis" Vasile Goldis" Arad. Seria Stiintele Vietii (Life Sciences Series), 2014, 24(2):251-256

[11] Dimins F, Mikelsone V, Kuka P, Jefremovs A N. Effect of different types of heat treatment on invertase activity in honey. In 9th Baltic Conference on Food Science and Technology “Food for Consumer Well-Being”, 2014, pp. 284-288

[12] Costa L C, Kaspchak E, Queiroz M B, Almeida M M, Quast E, Quast L B. Influence of temperature and homogenization on honey crystallization. Brazilian Journal of Food Technology, 2015, 18(2):155-161

[13] Silva T M, dos Santos F P, Evangelista-Rodrigues A, da Silva E M, da Silva G S, de Novais J S, dos Santos F D, Camara C A. Phenolic compounds, melissopalynological, physicochemical analysis and antioxidant activity of jandaíra (Melipona subnitida) honey. Journal of Food Composition and Analysis, 2013, 29(1):10-18

[14] Gomes T, Feás X, Iglesias A, Estevinho L M. Study of organic honey from the northeast of Portugal. Molecules, 2011, 16(7):5374-5386

[15] Goldstein M. Moisture and humidity. In The complete idiot's guide to whether. Indianapolis: Alpha Books, 2002, pp. 13-15

[16] Adams M. R., Moss M. O. Food microbiology. New Delhi: Panima Publishing Corporation, 2003

[17] Wilczyńska A, Ruszkowska M. Water activity and colour parameters changes during storage of linden and buckwheat honeys. Zeszyty Naukowe Akademii Morskiej w Gdyni, 2014, (84):174-181 
[18] Manikis I, Thrasivoulou A. The relation of physicochemical characteristics of honey and the crystallization sensitive parameters. Apiacta, 2001, 36(3):106-112

[19] Escuredo O, Míguez M, Fernández-González M, Seijo M C. Nutritional value and antioxidant activity of honeys produced in a European Atlantic area. Food Chemistry, 2013, $138(2): 851-856$

[20] Perez-Arquillué C, Conchello P, Ariño A, Juan T, Herrera A. Quality evaluation of Spanish rosemary (Rosmarinus officinalis) honey. Food Chemistry, 1994, 51(2):207-210

[21] Conti M E. Lazio region (central Italy) honeys: A survey of mineral content and typical quality parameters. Food Control, 2000, 11(6):459-463

[22] Karabagias I K, Louppis A P, Karabournioti S, Kontakos S, Papastephanou C, Kontominas M G. Characterization and geographical discrimination of commercial Citrus spp. honeys produced in different Mediterranean countries based on minerals, volatile compounds and physicochemical parameters, using chemometrics. Food Chemistry, 2017, 217:445-455

[23] Khalil M I, Sulaiman S A, Gan S H. High 5-hydroxymethylfurfural concentrations are found in Malaysian honey samples stored for more than one year. Food and Chemical Toxicology, 2010, 48(8):2388-2392

[24] Biluca F C, Braghini F, Gonzaga L V, Costa A C, Fett R. Physicochemical profiles, minerals and bioactive compounds of stingless bee honey (Meliponinae). Journal of Food Composition and Analysis, 2016, 50:61-69

[25] Lupano C E. DSC study of honey granulation stored at various temperatures. Food Research International, 1997, 30(9):683-688

\section{How to cite this article:}

Fuad AMA, Anwar NZR, Zakaria AJ, Shahidan N, Zakaria Z.Physicochemical Characteristics of Malaysian Honeys Influenced by Storage Time and Temperature. J. Fundam. Appl. Sci., 2017, 9(2S), 841-851. 